\title{
DIE PASGA EN SY BOODSKAP IN DIE TYD VAN DIE OU TESTAMENT
}

\author{
H.F. van Rooy \\ Potchefstroomse Universiteit vir Christelike Hoër Onderwys \\ POTCHEFSTROOM
}

\begin{abstract}
PASSOVER AND ITS MESSAGE IN OLD TESTAMENT TIMES

In this article the Passover and its message in Old Testament times ane discussed, with special reference to the message of the Passover in Exodus 12; during the reform of King Josiah of Judah; the message of the Passover as celebrated by the exiles retuming from Babylonia; and the message of the Passover for the people for whom the Chronicles were written. The discussion of the message of the Passover in these instances is preceded by a discussion of the references to the Passover in the books of the Old Testament. It is concluded that the Passover only had meaning when linked to repentance and the service of God. It served to remind the people of God's grear deeds in the past, such as the exodus from Egypt, and as such it pointed to the possibility of great deeds of deliverance in the future. The Passover had a positive meaning only for believers.
\end{abstract}

\section{INLEIDING}

Die Pasga is van die verskillende feeste wat in die Ou Testament vermeld word, die een wat vir die kerk waarskynlik die meeste beteken, juis omdat die instelling van die Nagmaal in die Nuwe Testament aan die Pasga verbind word (vergelyk Childs, 1974:212). Dit is ook so dat sekere Nuwe Testamentiese verwysings na Jesus pertinent aan sake rakende die Pasga verbind kan word. Die bekendste hiervan is sekerlik die verwysing na Jesus as die Paaslam, soos aangetref in 1 Korintiers 5:7 (waar die verwysing na die suurdeeg ook met die Pasga verband hou), 1 Petrus 1:19, Johannes 19:36, Openbaringe 5:6,9 en 12 en 12:11 (vergelyk Schaller, 1975:634).

Hierdie artikel handel oor die inhoud en boodskap van die Pasga as deel van die agtergrond vir die verstaan van die Nagmaal. Daar sal dus nie aandag gegee word aan die aansluiting van die Nagmaal by die Pasga nie, aangesien dit deur ander skrywers behandel word.

Vir die verstaan van die betekenis van die Pasga is dit nodig om te kyk na dit wat die Ou Testament daaroor leer, en veral na dit wat die boodskap van die Pasga vir die OuTestamentiese gelowiges in verskillende tye was. Gevolglik gaan daar in hierdie artikel 
meer aan die orde kom as bloot die formele vraag na wat die Pasga was. Volgens Eksodus 12:24-27 was die Pasga ook bedoel as 'n boodskap vir die verdere geslagte. Daarom is dit nodig om te kyk na wat die boodskap vir verskillende geslagte in verskillende omstandighede was. Wat hierdie boodskap van die Pasga in verskillende tye betref, moet daar twee sake onderskei word. Daar kan aan die een kant verwys word na die boodskap van die Pasga in die tyd toe dit ingestel of gevier is. Aan die ander kant kan verwys word na die boodskap van die Pasga vir die lesers van 'n spesifieke boek (waarin daar 'n beskrywing van die Pasga of die viering daarvan is). Daar sal in die besonder gelet word op die boodskap van die Pasga, eerstens soos dit aangetref word in Eksodus 12, tweedens tydens die hervormings van Josia, derdens vir diegene wat uit die Babiloniese ballingskap teruggekeer het en vierdens vir diegene tot wie Kronieke gerig was. In die geval van die eerste drie sake sal daar veral gelet word op die boodskap van die Pasga in die situasie van diegene wat dit beleef het en wat in die gedeeltes beskryf word, terwyl in die geval van Kronieke gelet word op die boodskap van die boek vir die lesers daarvan. Daar sal afgesluit word met 'n kort samevatting van die belangrikste elemente van die Pasga en die boodskap daarvan soos dit uit die verskillende periodes blyk.

'n Basiese uitgangspunt wat die artikel ten grondslag lê, is dat die verskillende boeke van die Ou Testament geskryf of saamgestel is met 'n sekere gehoor in gedagte. Dit geld ook vir die historiese boeke, wat nie bloot geskiedenis wil weergee nie, maar wat deur die verhaal van gebeure 'n boodskap wou bring vir die oorspronklike lesers. In hierdie boodskap het ook die berigte oor die viering van die Pasga ' $n$ plek. Vir die verstaan van die boodskap is dit nodig om te let op wie die adres van betrokke b- ek was.

\section{DIE PASGA IN DIE OU-TESTAMENTIESE BOEKE}

Daar is ' $n$ hele aantal direkte en indirekte verwysings na die Pasga in die Ou Testament. Omdat dit onmoontlik is om aan al die gedeeltes aandag te gee, word die vernaamstes hier net kortliks aangedui. Daar is verskillende verwysings in die Ou Testament na die instelling van die Pasga, waaronder die verwysing in Eksodus 12 die volledigste is. Verder word voorskrifte vir die onderhouding van die Pasga aangetref in Deuteronomium 16 en Numeri 9. Verdere korter bepalings oor die Pasga word aangetref in Eksodus 34, Levitikus 23 en Numeri 18. Benewens die verwysing na die viering van die eerste Pasga in 'n aantal historiese gedeeltes, naamlik Josua 5, 2 Konings 23 (met sy parallel in 2 Kronieke 35), 2 Kronieke 30 en Esra 6, word daar ook in Numeri 9 verwys na die viering van die Pasga. Die vierings van die Pasga wat vermeld word, is die eerste Pasga, in Egipte net voor die uittog (Eksodus 12), die volgende Pasga in die woestyn in die tweede jaar na die uittog (Numeri 9), die Pasga in die tyd van Josua, in 
die beloofde land na die intog (Josua 5), die Pasga in die tyd van Hiskia, verbind aan sy godsdienstige hervormings (2 Konings 23 en 2 Kronieke 35) en die Pasga na die terugkeer uit die ballingskap, met die herstel van die tempel (Esra 6).

Daar moet ook in gedagte gehou word dat die Pasga met die verloop van tyd 'n verandering ondergaan het. In Eksodus 12 word die Pasga beskryf as 'n fees wat aan gesinne verbind was, terwyl dit in Deuteronomium 'n fees geword het wat alleen by die sentrale heiligdom gevier moes word. Die sentralisering van die godsdiens van Israel was een van die faktore wat bygedra het tot die veranderinge wat daar met die verloop van tyd in die viering van die Pasga gekom het, asook die verandering van die volk se bestaan van 'n nomadiese bestaan na ' $n$ meer gevestigde bestaan (vergelyk De Vaux, 1976:486). In Eksodus 12:20 staan daar dat die pasga' in al die woonplekke van die volk geëet moes word, terwyl in Deuteronomium 16:5 en 6 bepaal word dat dit nie oral in die land gevier mag word nie, maar alleen op die plek wat die Here sal uitkies om sy naam daar te laat woon. Alhoewel dit duidelik is dat die Pasga en die fees van die ongesuurde brode 'n lang geskiedenis gehad het, is die presiese verloop van die geskiedenis nie duidelik nie (Childs, 1974:187; vergelyk ook Van Seters, 1983:178-182 en De Vaux, 1976:484-493).

\section{DIE PASGA IN EKSODUS 12}

Wat die boodskap van die Pasga in Eksodus 12 betref, is dit dadelik duidelik dat die fees aan die uittog uit Egipte verbind word. Dit kom onder andere na vore in vers 14, waar die dag van die uittog, die dag waarop die Pasga gevier moet word, 'n gedenkdag genoem word. Die boodskap van die Pasga moes aan die komende geslagte oorgedra word, sodat ook hulle sou kennis neem van die groot dade van God in die verlede. Dit word ook uitgespel in vers 24-27. Die Pasga moes vir die volk dien as 'n herinnering aan dit wat God vir hulle gedoen het. Aan die einde van Eksochs 12 word dit ook bepaal dat die Pasga alleen bedoel was vir die Israeliete en diegene wat hulle by die volk gevoeg het. Sodoende het die Pasga ook daarop gedui dat die volk afgesonder was van die ander volke. Die Pasga moes dus ook daartoe dien om die volk aan God te verbind. Deur sy verlossende daad het die volk as volk tot stand gekom.

Die beskrywing van die Pasga in Eksodus 12 word grotendeels aan P toegeskryf, met as uitsondering vers 21-28, wat aan J toegeskryf word (Rylaarsdam, 1952:916-926, De Vaux, 1976:485, 492). ${ }^{2}$ Die verhaal in sy huidige vorm word dus as laat beskou. Tog

1 pasga (dic dicr wat geslag moes word - vergelyk Deuteronomium 16:5).

Pasga (die fees) 
gaan die verhaal waarskynlik op vroeë tradisies terug (vergelyk Fensham, 1970:10), sodat dit gebruik kan word om ten dele die boodskap van die Pasga in die tyd van die gebeure in Eksodus beskryf, te bepaal. Die fees het veral daartoe gedien om die volk aan God en sy reddende optrede in die geskiedenis te verbind.

\section{DIE PASGA IN DIE TYD VAN JOSIA}

Die beskrywing van die Pasga wat in die tyd van Josia gevier is, word aangetref in 2 Konings 23 en in 2 Kronieke 35. In hierdie gedeelte sal daar egter net op 2 Konings 23 gefokus word, veral in verbinding met die voorskrifte wat in Deuteronomium 16 aangetref word. 2 Kronieke se beskrywing van die episode sal aan die orde kom wanneer die boodskap van Kronieke in verband met die Pasga bespreek word.

Die keuse van Deuteronomium 16 as agtergrond vir 2 Konings 23 hang veral met twee sake saam. Die eerste is die duidelike verband wat daar tussen die boek Deuteronomium en die boeke Josua, Rigters, Samuel en Konings is. Dat hierdie historiese boeke saam algemeen bekend staan as die Deuteronomistiese geskiedwerk getuig van die nou band wat daar tussen die werke en Deuteronomium gesien word. Hierdie boeke beskryf die geskiedenis van die Israeliete van die intog in die beloofde land tot met die Babiloniese ballingskap. Die perspektief wat dikwels uit die boeke spreek, onder andere in beoordelings wat van verskillende konings gegee word, hang nou saam met die prediking van Deuteronomium (vergelyk Van Rooy, 1988:864-865 vir 'n meer volledige bespreking hiervan). Die tweede rede vir die keuse van Deuteronomium as agtergrond is die band tussen die boek en die hervormings van Josia. Dit is goed bekend dat een van die basiese uitgangspunte in die historiese kritiek was dat Deuteronomium juis aan die hervormings van Josia verbind moet word. Selfs baie van diegene wat nie aanvaar dat Deuteronomium (ten dele minstens) in die sewende eeu voor Christus ontstaan het nie, aanvaar wel dat die boek 'n besondere plek in Josia se hervormings gehad het en dat dit dalk die wethoek was wat in die tempel gevind is (vergelyk LionCachet, 1988:312-313).

In die voorskrifte vir die Pasga, soos aangetref in Deuteronomium 16:1-8, kan die volgende elemente onderskei word:

- Die datum word gestel in die maand Abib en die maand word spesifick verbind aan die uittog uit Egipte (vers 1).

- Die Pasga moet gevier word op die plek wat God daarvoor uitkies en nie op enige plek in die

2P (Priesterlike bron), J (Jahwistiese bron). 


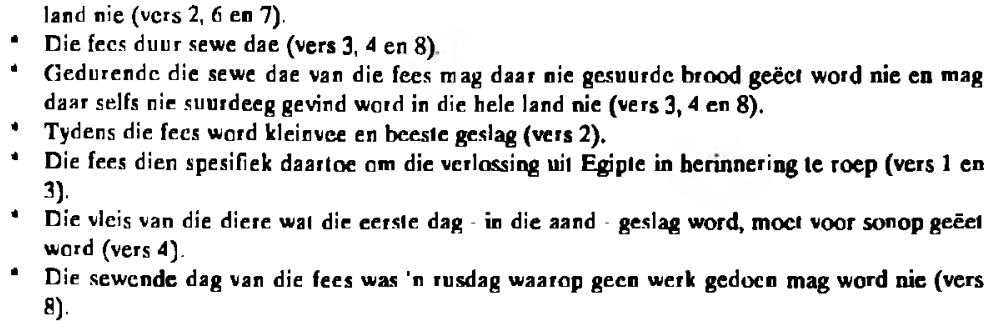

Wat die beskrywing van die Pasga in die tyd van koning Josia in 2 Konings 23 betref, is dit so dat slegs drie verse (21-23) daaraan gewy word. Dit is 'n kort beskrywing waarin bloot die feit van die viering van die Pasga vermeld word, sonder om breedvoerig op al die detail van die viering in te gaan. Tog is daar in die kort beskrywing 'n aantal sake wat verbind kan word aan die voorskrifte in Deuteronomium. Belangrik is die vermelding aan die einde van die kort beskrywing dat die Pasga in Jerusalem gevier is. Dit sluit natuurlik aan by die voorskrif van 'n sentrale fees, wat weer verband hou met die besondere klem wat die sentralisering van die diens van God in die hervormings van Josia gekry het. Verder word daar gese dat so 'n Pasga sedert die dae van die Rigters en deur die tyd van die konings nie in Israel plaasgevind het nie. In die opset van die Deuteronomistiese geskiedwerk is dit so dat die verwysing na die Pasga in die tyd van Josia die eerste is wat aangetref word sedert die tyd van Josua. 'n Derde belangrike saak wat aangetref word, is die verwysing na "hierdie verbondsboek" in vers 21 . Hierdie boek, waarna meermale verwys word in die beskrywing van die hervormings van Josia, moet beslis aan Deuteronomium verbind word, al is dit nie die boek in presies die finale vorm daarvan nie. Die betekenis hiervan is dat die Pasga in die tyd van Josia dus gehou is naastenby volgens die voorskrifte van Deuteronomium 16 (vergelyk ook Rehm, 1982:227).

Wat die betekenis van hierdie Pasga in die tyd van Josia betref, moet dit beoordeel word teen die agtergrond van die hervormings van Josia. Soos dit in 2 Konings beskryf word, het hierdie koning opgetree om die godsdienstige verval van die volk teen te gaan. Die wetboek wat gevind is, het duidelik gemaak dat die volk die verbond met God, soos uitgedruk in die voorskrifte wat veral in Deuteronomium 12-26 aangetref word, verbreek het. Dit het die volk onder die vloeke wat in Deuteronomium 28 uitgespreek is, gestel. Josia het onder die besef gekom dat die volk hulle moes bekeer. Hiervoor het hy teen die die afgodediens opgetree, die hoogtes vernietig en die diens van die Here in Jerusalem gesentraliseer. Die beskrywing van die Pasga volg op die beskrywing van die uitroeiing van die afgodsdiens. Die Pasga het die doel gedien om 
die volk terug te bring van die verkeerde godsdiens na die diens van die ware God en moes die volk daartoe bring om God op die regte wyse te dien. In die Pasga is daar die verwysing na die verlossing wat God reeds gebring het en dit sluit ook die belofte in dat God weer sy genade sal bewys aan diegene wat Hom opreg dien. Die viering van die Pasga as deel van die godsdienstige hervormings van Josia moes ook dui op die wettigheid en noodsaaklikheid van die hervormings.

Uit die verdere geskiedenis, soos beskryf in 2 Konings, is dit egter duidelik dat die hervormings van Josia nie werklik tot die harte van die volk deurgedring het nie. Selfs nie eers die seuns van Josia wat hom opgevolg het, het hulle met hulle hele hart tot God gewend nie. Bloot die feit dat die Pasga gevier is, het nie die volk van God se oordeel gevrywaar nie. By Josia was die hervorming verbind aan 'n hartgrondige bekering (2 Konings 22:19). Daarsonder het ook die viering van die Pasga nie sin nie. Die werklike boodskap van die Pasga het nie tot die volk deurgedring nie en daar was nie by die volk sprake van 'n werklik hartgrondige bekering nie. Op die ou end is die volk weens hulle sonde in ballingskap weggevoer - en die volgende viering van die Pasga waarna verwys word, was na die terugkeer uit die ballingskap. Daar moet verder in gedagte gehou word dat die boeke van die Konings hulle finale vorm tydens die ballingskap gekry het en onder andere daarop gemik was om die volk te laat besef dat God se oordeel regverdig was. Die kommentaar wat op die hervormings van Josia volg (2 Konings 23:25-27) moes ook daartoe gedien het om die ballinge te laat besef dat bloot die onderhouding van 'n fees geen waarborg kan wees van God se nabyheid nie. Vir hulle moes dit duidelik gewees het dat die viering van die Pasga in die dae van Josia nie blywende waarde gehad het nie, omdat dit nie met hartgrondige bekering gepaard gegaan het nie. Vir die ballinge bring die boek 'n boodskap van berou en bekering - en 'n bloot uitwendige feesviering het hierin nie 'n plek nie.

\section{DIE PASGA NA DIE TERUGKEER UTT DIE BALLINGSKAP}

In Esra 6:16-22 word verhaal hoedat die volk na die terugkeer uit die ballingskap en na die voltooiing van die tempel weer die Pasga gevier het met die ingebruikneming van die herboude tempel. Daar is eers offers gebring vir die tempelwyding (vers 16-18) en daarna word die viering van die Pasga beskryf in vers 20-22. Waar die beskrywing van die Pasga in die tyd van Josia verband hou met die voorskrifte in Deuteronomium 16, hou hierdie beskrywing eerder verband met die verhaal van die instelling van die Pasga in Eksodus 12.

Die volgende sake word in die beskrywing van die Pasga in Esra 6 aangetref. 
- Dic datum was die vecrtiende van die eerste maand.

- Daar word vermeld dat dic priesters en die Leviete hulle gereinig het voordat die lam geslag is.

- Die Pasga is gevier deur dic teruggekeerde ballinge en dicgene wat in die land oorgebly het en dit word spesifiek vermeld dat hierdic deelnemers aan die fees hulle van die onreinheid van die nasies afgesonder hel.

- Die viering van die Pasga word ook verbind aan die fees van die ongesuurde brode, 'n fees wat sewe dae geduur het.

* Die lam wat geslag is, word hier spesifiek vermeld.

Van hierdie sake verbind bogenoemde gedeelte aan Eksodus 12 - in teenstelling tot Deuteronomium 16. In Eksodus word die maand ook die eerste maand genoem, terwyl Deuteronomium praat van die maand Abib. In Eksodus word daar eksplisiet na die lam verwys wat geslag moet word, soos ook in Esra 6, terwyl daar in Deuteronomium 16 na die pasga wat geslag moet word, verwys word, en ook na skape en beeste, maar nie na die lam nie. In Deuteronomium 16 is daar ' $n$ kort verwysing na die fees van die ongesuurde brode aan die einde van die gedeelte wat oor die Pasga handel, maar in Eksodus 12 word daar baie meer uitvoerig daarna verwys en vorm dit deel van die instelling van die Pasga. Wat die afsondering van die nasies betref, kan daar'n ooreenkoms gesien word tussen Esra 6 en die gedeelte aan die einde van Eksodus 12 wat daaroor handel of vreemdelinge van die Pasga mag eet of nie. Hierdie gegewens saam dui aan dat die beskrywing van hierdie Pasga na die terugkeer uit die ballingskap en die herbou van die tempel met die berig in Eksodus 12 verbind kan word. Dit sou ook verbind kan word met die beskrywing in Numeri 9, waar dieselfde tydaanduiding gebruik word en waar daar ook van reinheid gepraat word. Dit is egter duidelik dat Numeri 9 ook by Eksodus 12 aansluit, met die byvoeging van die saak van onreinheid van diegene wat 'n lyk aangeraak het. Van die ander sake in Esra 6 vermeld, word egter nie ook in Numeri 9 aangetref nie, sodat dit beter is om die vergelyking tot Eksodus 12 te beperk.

Wat die betekenis van die Pasga vir die teruggekeerde ballinge betref, is dit belangrik om die verbinding van die Pasga met die herboude tempel raak te sien. Die voltooiing van die tempel in 515 v.C. was 'n baie belangrike gebeurtenis in die geskiedenis van die volk van God. Daarmee is die terugkeer uit die ballingskap eintlik afgerond. Die vernietiging van die tempel in Jerusalem deur Nebukadneser het vir die volk duidelik getoon dat hulle aan God se oordeel nie kon ontkom nie. Die straf het oor hulle gegaan - en selfs na die terugkeer uit die ballingskap het dit nie gelyk of die straf verby was nie. Daar was stryd in die gemeenskap tussen verskillende groepe en teen die vyande van die volk. Die voltooiing van die tempel het getoon dat in beginsel ten minste 'n deel van die stryd afgehandel was. In die viering van die Pasga is daar terug- 
gedink aan die verlossing uit Egipte, sodat die terugkeer uit Babel eintlik as 'n tweede Eksodus beskou kon word. Daar word ook klem gelê op die reinheid van die volk wat hulle van die nasies afgesonder het. Die volk wat ballinge was, het nou weer 'n volk in eie reg geword, rondom die tempel as die nuwe saambindende faktor in die gemeenskap. Deur die viering van die Pasga is die herboude tempel verbind aan 'n ou tradisie van die volk en is die volk bemoedig deur die herinnering aan die magtige dade van God in die verlede. Daarin lê die belofte ingesluit dat God weer aan sy volk verlossing sal skenk. Hierdie Pasga getuig dus van 'n herstelde verhouding, van nuwe verlossing en van voortgaande genade. Dit moet dus raakgesien word dat die Pasga nie net terugkyk nie, maar dat die verlossing waarvan dit spreek ook in die hede as ' $n$ werklikheid beleef word. Dit spreek van God se reddende teenwoordigheid, dit versterk die bande in die gemeenskap wat die Pasga vier en dit gee krag vir die toekoms (vergelyk Holmgren, 1987:51-53).

\section{DIE PASGA IN KRONIEKE}

Wanneer die gegewens oor die viering van die Pasga in die boeke vanaf Josua tot 2 Konings met Kronieke, Esra en Nehemia vergelyk word, is dit dadelik opvallend dat daar baie meer aandag aan die Pasga in die kronistiese boeke gegee word. In die eerste groep, die sogenaamde Deuteronomistiese geskiedwerk, word daar net by twee geleenthede van die Pasga melding gemaak. Die een is in Josua 5, waar die Pasga na die intog in die beloofde land vermeld word. Die viering van die Pasga word in een vers, vers 11 , beskryf. Die tweede verwysing is na die Pasga in die tyd van Josia, wat in 2 Konings 23 in drie verse (21-23) bespreek word. In die vier kronistiese boeke word daar beskrywings van drie Pasgas aangetref, naamlik die Pasga in die tyd van Hiskia, in die tyd van Josia en met die inwyding van die herboude tempel na die terugkeer uit die ballingskap. Die Pasga in die tyd van Hiskia word in 2 Konings glad nie vermeld nie, terwyl 2 Kronieke 30 'n uitvoerige beskrywing daarvan gee (in 27 verse). Die Pasga van Josia word in 2 Kronieke 35 (in 19 verse) uitvoerig beskryf - terwyl dit in 2 Konings 23 in drie verse afgehandel word. Soos in die vorige afdeling aangedui, word die Pasga met die inwyding van die tempel (515 v.C.) in Esra 6 in vier verse bespreek. Uit hierdie gegewens is dit duidelik dat die skrywer(s) van die kronistiese boeke baie aandag gegee het aan die viering van die Pasga. Die Pasga in die tyd van Josua word nie in Kronieke beskryf nie,maar dit hang saam daarmee dat die hele periode wat deur die boeke Josua en Rigters beskryf word, geen aandag in Kronieke kry nie. Die meerdere aandag wat die Pasga in Kronieke kry, maak die vraag na die boodskap van die Pasga vir diegene vir wie die boeke geskryf is, soveel te meer belangrik. 
Die vraag wie presies die adres van hierdie boeke was, is hier nie so maklik om te beantwoord nie. Dat 1 en 2 Kronieke en Esra en Nehemia verband hou (vergelyk Van Dyk, 1987:78-82 vir 'n bespreking van die verhouding tussen die boeke), is wel duidelik, maar dit maak die vraag na die presiese adres nie baie makliker nie. Sonder om op al die argumente in te gaan, is dit baie waarskynlik dat die boeke geskryf is teen die middel van die vierde eeu voor Christus (vergelyk Ackroyd, 1973:27). Dit plaas dit ongeveer tweehonderd jaar na die afronding van die Deuteronomistiese geskiedwerk en steeds in die Persiese periode. In daardie tyd was die koningshuis van Dawid reeds lankal van die toneel - selfs Serubbabel se optrede was 150 jaar of meer tevore. Die teruggekeerde ballinge se nageslag het nie meer werklik die verwagting gehad van 'n spoedige herstel van die onafhanklikheid van die Jode nie. Selfs die tyd van Esra en Nehemia is al verby. Dit is 'n tyd, hier teen die middel van die vierde eeu, waarvan daar nie so veel besonderhede oor die lotgevalle van die mense in en om Jerusalem bekend is nie. Tog wil die skrywer van die boeke 'n boodskap vir die mense van sy tyd bring. Deur die geskiedenis wys hy hulle op die patroon wat in die geskiedenis van Israel nagespeur kan word, die patroon van oortreding en oordeel, genade en herstel, wat soos 'n goue draad deur die geskiedenis van Israel loop. Die volk van God in daardie tyd was nie meer 'n onafhanklike staat nie, maar onderdane van die Persiese ryk. Deur die werk van onder andere Esra en Nehemia was die volk wel godsdienstig gebind aan die wette en die tempel as die sentrum van hulle godsdiens. Teen hierdie agtergrond kan die belangstelling van die kronis in die tempel, die tempeldiens en die plek van die priesters en Leviete goed verstaan word (Schmidt, 1984:168-169). Sommige wil die boeke wel vroeër of later dateer as die middel van die vierde eeu. Labuschagne wil die eerste redaksie van Kronieke plaas teen 500 v.C. en die finale redaksie teen 400 v.C. (1979:120). Hy wil die boeke veral verbind aan die tyd na die herbou van die tempel en beskou dit as die bloudruk vir die gemeenskap van die tweede tempel gelei deur die Levitiese priesters onder die leiding van Serubbabel (1979:122-123). Ook Newsome wil die boeke vroeër dateer en dit selfs verbind aan die beweging waartoe Haggai en Sagaria behoort het (1975:216). Curtis is weer'n voorbeeld van diegene wat die boeke later wil dateer, teen ongeveer 300 v.C. (1965:5-6). Tog maak selfs hierdie daterings nie wesentlik verskil nie. Die adres van die boeke was mense wat nie in 'n onafhanklike staat geleef het nie en die skrywer wou hulle onder andere daarop wys dat hulle eenheid godsdienstig van aard is. Hierin het die tempel en die feeste 'n besondere plek gehad.

Wat die boodskap van die Pasga vir die adres van Kronieke betref, is die beskrywings van die Pasga in die tyd van Hiskia (2 Kronieke 30) en Josia (2 Kronieke 35:1-19) van belang. Dit is reeds vermeld dat 2 Konings die Pasga in die tyd van Hiskia glad nie vermeld nie en dat die beskrywing van die Pasga van Josia in Konings baie kort is. Die 
langer beskrywing van die Pasga in Kronieke hou ongetwyfeld verband met die bedoeling van die outeur in die tyd van die tweede tempelgemeenskap. Sy adres was mense wat veral saamgebind was om die herboude tempel. Gevolglik is dit nie vreemd dat hy besondere aandag gee aan die twee hervormings van die konings van Juda waarin die tempel en die Pasga 'n besondere rol gespeel het nie (vergelyk Eybers, 1978:243).

In die beskrywing van die Pasga in die tyd van Hiskia word 'n hele aantal elemente aangetref wat vir die adres van Kronieke 'n besondere boodskap moes ingehou het. Die volgende kan onderskei word:

- Dic verbinding van die Pasga aan godsdienstige hervormings.

- Dic feit dat dic Pasga 'n sentrale fees was wat eers na voldoende rciniging kon plaasvind.

- Die Pasga is uitgestel weens die onreinheid van die volk, wat herinner aan die gebeure in Numeri 9 (vcrgelyk Fishbane, 1980:345-346).

- Die verbinding van die viering van die Pasga aan bekering en die ontrou van dic vorige geslagte.

- Dic rol van die Levicte en die priesters in die viering van die Pasga.

- Die viering van die Pasga volgens die voorskrifte van Moses.

Ook in die beskrywing van die Pasga in die tyd van Josia kom verskeie van die elemente weer na vore, spesifiek die verbinding aan godsdienstige hervorming, reiniging, en die rol van die priesters en die Leviete en die viering van die Pasga volgens die voorskrifte van Moses. Die voorskrifte van Moses word nie nader aangedui nie en dit mag hier 'n omvattende uitdrukking wees wat na verskillende voorskrifte verwys.

Die boodskap van die twee vierings van die Pasga (volgens Kronieke) kan verbind word aan die plek van die tempel in daardie tyd. In albei die beskrywings word die plek van die tempel en die rol van die priesters en die Leviete besonder beklemtoon, asook die sentralisering van die fees in Jerusalem. Dit is wel merkwaardig dat in nie een van die twee gedeeltes die Pasga aan die verlossing uit Egipte verbind word nie, terwyl dit in Eksodus 12 en Deuteronomium 16 uitdruklik vermeld word. Die volk word egter gewys op die belangrike plek wat die tempel en feeste soos die Pasga in hulle lewe moet hê. Die Pasga spreek vir hulle van God se nabyheid, in die verlede en ook in die hede en vir die toekoms. Wie se lewe om die tempel en die diens daarin draai, word verseker van God se genade. Ook word hulle gebind in 'n onderlinge band met mekaar, as deelgenote aan hierdie besondere fees. Die belangrike plek wat die priesters en Leviete in die viering van die Pasga gehad het (volgens 2 Kronieke) het ook die al hoe belangriker plek wat die priesters en Leviete in die tweede tempelperiode ingeneem het, onderstreep. 


\section{DIE BOODSKAP VAN DIE PASGA}

Uit die bespreking van die boodskap van die Pasga in die verskillende tye kan sekere basiese lyne onderskei word waarin die boodskap veral na vore kom. Die Pasga is verbind aan die regte diens van God en het teenoor sake gestaan wat in die boeke van die Ou Testament afgewys word, soos die diens op die hoogtes. Dit word meermale verbind aan godsdienstige hervormings en moes die volk ook oproep tot die ware diens van God. Op hierdie wyse het daar 'n boodskap van berou en bekering van die Pasga uitgegaan. Bloot die viering van die fees was nie 'n waarborg van God se genade nie. Die fees moes die volk daarop wys dat hulle 'n afgesonderde volk is wat volgens die voorskrifte van God moes leef. As hulle dit nie sou doen nie, sou die Pasga sy betekenis verloor het.

Die Pasga het ook daartoe gedien om die volk se aandag te vestig op die magtige dade van God in die verlede. Dit het heengewys na die verlossing uit Egipte en na vroeëre vierings daarvan met besondere geleenthede. In hierdie verwysing na die magtige dade van God in die verlede lê in kiem die belofte van nuwe verlossende dade in nuwe omstandighede. So spreek die Pasga ná die godsdienstige hervormings van Hiskia en Josua van 'n herstelde verhouding tussen God en sy volk. Deur die herstelde verhouding met God word die volk ook onderling saamgebind as 'n godsdienstige eenheid. Die Pasga wys die volk op die belang daarvan om God met 'n opregte en berouvolle hart te dien. Alleen op daardie wyse het die Pasga vir hulle betekenis gehad. Los van hulle geloof het dit sy waarde verloor.

\section{BIBLIOGRAFIE}

ACKROYD, P R 1973 I \& II Chronicles, Ezra, Nchemia. London: SCM (Torch Bible Paperbacks.)

CHILD, B S 1974. The book of Exodus. Philadelphia: Westminster Press. (Old Testament library.)

CURTIS, E.L. 1965. The books of Chronicles. Fdinburgh : Clark. (International Critical Commentary.)

DE VAUX, R. 1976. Ancient Isracl. Its life and institutions London : Darton, Longman \& Todd.

EYBERS, I.H 1978. Gods Woord in mensetaal IIl. Die ontstaan, inhoud en boodskap van die "geskrifte" in die Hebreeuse kanon. Durban: Butterworth

FENSHAM, F.C. 1970. Exodus. Nijkerk : Callenbach. (De prediking van het Oude Testament.)

FISHBANE, $M .1980$ Revelation and tradilion: aspects of inner-Biblical exegesis. Joumal of Biblical Literalure, 99:343-361.

GRAY J. 1970. I and II Kings. London: SCM. (Old Testament library.)

LABUSCHAGNE, C.J. 1979. Gods oude plakbock. 's Gravenhage : Boekencentrum.

HOLMGREN, F.C. 1987. Ezra and Nehemia Israel alive again. Grand Rapids : Eerdmans (Inlernalional theological commentaries)

LION-CACHET, F.N. 1988. Deuteronomium - gister en vandag. Koers, 53:305-330. 
NEWSOME, J.D. 1975. Toward a new understanding of the Chronicler and his purpose. Joumal of Biblical Literature, 94:201-217.

REHM, M 1982. Das zweile Buch der Könige. Wurzburg : Echler Verlag

RYLAARSDAM, J.C. 1952. The book of Exodus New York, NJ. : A bingdon. (The Interpreter's Bible I, p. 831-1099.)

SCHALlER, B. 1975. Passover. (In Brown, C. red. The new international dictionary of New Testament theology 1. Grand Rapids : Zandervan 0.632-634.)

SCHMIDT, HW 1984. Old Testament introduction. New York : Crossroads.

VAN DYK, PJ. 1987. Die Kronistiese geskiedwerk (In Bosman, H.L. en Loader, J.A., reds. Vertellers van die Ou Tesiament. Die literatuur van die Ou Tesiamenı deel 2. Kaapstad: Tafelberg. p.7599).

VAN ROOY, H.F. 1988. Verbond en vergewing: Deuleronomium 29 en 30 en die Deuteronomistiese geskiedwerk. Herwomde Teologiese Studies, 44:864-882.

VAN SETERS, J. 1983. The place of the Yahwist in the hislory of Passover and Massot. Zeitschrift fïr die altestamentliche Wissenschaft, 95:167-182 